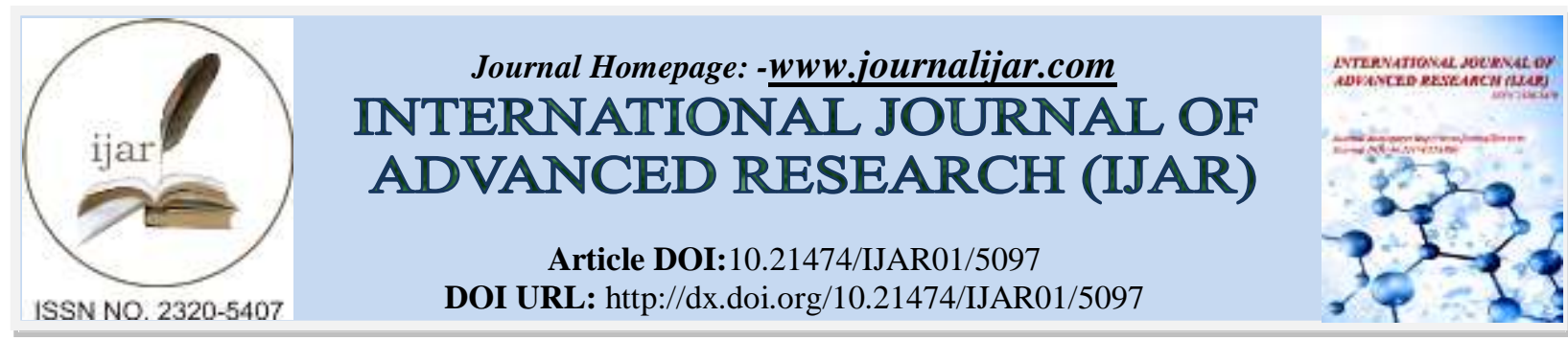

RESEARCH ARTICLE

\title{
MANAGEMENT OF SANDHIGATA VATA (JANU SANDHI) WITH AYURVEDIC APPROACH: A CASE STUDY.
}

\author{
Parveen Kumar ${ }^{1}$ and Smita Kumari ${ }^{2}$. \\ 1. Asstt. Prof. Deptt. of Panchkarma. Dayanand Ayurvedic College, Jalandhar. Punjab. \\ 2. Asstt. Prof. Dayanand Ayurvedic College, Jalandhar. Punjab.
}

\section{Manuscript Info}

Manuscript History

Received: 07 June 2017

Final Accepted: 09 July 2017

Published: August 2017

Key words:-

Sandhigata Vaata, Ayureda,

Osteoarthritis, Patra Pinda Swedana.

\begin{abstract}
Being commonest form of articular disorders, sandhigata vata poses a huge hindrance in day to day activities of the sufferer like walking, dressing and bathing etc. It is a disease of old age. It mainly affects weight-bearing joints of the body specially knee, hip, lumbar spine. As per Ayurveda, shula, Sotha, Vata poornadriti sparsha and difficult in flexion and extension of the Sandhi are the symptoms. Here is a case of bilateral knee Osteoarthritis who was advised arthroplasty. After completion of the therapy, significant improvement was seen in pain, swelling, range of movement and walking distance after treatment. The patient was successfully managed with internal medication \& Patra Pinda Swedan therapy. It is being seen that a large number of patients, after taking allopathic treatment for long durations, are coming to the Ayurveda hospitals and find very good relief. It can be concluded that severe osteoarthritis may be managed with Ayurvedic intervention.
\end{abstract}

Copy Right, IJAR, 2017,. All rights reserved.

\section{Introduction:-}

Sandhivata term is formed from two distinct words: sandhi, means a joint; and Vata, means one of the three doshas. Ayurvedic literature describes the disease under various names, which are Sandhivata ${ }^{1}$, Sandhigatavata, Khudavata and Jeernavata etc. Sandhigata vata has been described under Vatavyadhi. Acharya Charaka has made the first mention of the disease separately with the name Sandhigata anila. Vata vitiating ahaar and vihar like Ruksha aahara, Atimaithuna, Ativyayama (excessive exercise/work), Sheeta bhojana (cold food/drinks), Dhatukshaya and Roga Atikarshan ${ }^{2,3}$ are considered to be main causative factors. The clinical features of Sandhigatavata, as described in various Ayurvedic ancient texts are shula (joint pain), shotha (swelling), prasaarana-aakunchanayopravruttischa vedana (painful joint movement) and Vata poornadriti sparsha (affected Sandhi resembles a bag filled with air). These features resemble with those of Osteoarthritis ${ }^{4,5}$. Osteoarthritis (OA) is the most common form of arthritis. It is strongly associated with ageing and is a major cause of pain and disability in older people ${ }^{6}$. In OA affected persons, $80 \%$ are having some movement limitation and $20 \%$ are unable to perform major activities of daily living ${ }^{7}$. Osteoarthritis accounts for $0.6 \%$ of all Disability adjusted life years (DALYs) and $10 \%$ of DALYs due to musculoskeletal conditions. This burden accounted for $2.2 \%$ of global years of life lost due to disability (YLD) and $10 \%$ of all YLD from musculoskeletal disorders ${ }^{8,9}$.

Hip and knee osteoarthritis was ranked as the 11th highest contributor to global disability and 38th highest in Disability adjusted life years (DALYs) ${ }^{10}$. Janu Sandhigata Vata is an Asthi-Sandhigata Vyadhi, there is Kshaya of 
Asthi Dhatu due to insufficient supply of Poshaka Rasa ${ }^{11}$.The line of treatment for sandhivata is mainly focused on the alleviation of vata dosha. Vitiated vata dosha can be best treated with the use of oil ${ }^{12}$. Use of snehana with swedana over the affected part is also advised in the treatment of vatavyadhi which alleviates pain, stiffness and improves flexibility ${ }^{13}$.

\section{Case report:-}

A 58 year old female patient came in panchakarma opd of dayanand ayurvedic college, jalandhar, with the complaints of sandhi shoola i.e. Severe pain and swelling over both knee joints \& difficulty in walking since 2 years. The patient was taking allopathic treatment, though not regularly, but did not get relief. She was advised to get knee replacement done by orthopaedic surgeons. Examination of the patient revealed sandhi shotha (swelling) around both knee joints, tenderness $2+$, vatapurnadritisparsha (crepitus) in both knee joints. The range of movement was restricted for both extension and flexion, and the movements were limited to $110^{\circ}$ for flexion and extension was limited to $30^{\circ}$. Patient had slight pallor, vitals: pulse rate 74/min, regular; blood pressure was $132 / 80 \mathrm{~mm}$ of hg. Xray of the joints revealed joint space reduction in both the knee joint, more so in the medial compartment bilaterally, and mild osteopenia. The diagnosis of osteoarthritis was established on the basis of above findings. In consideration with the findings of clinical examination $\&$ investigations following treatment was given as table no. 1.

Table no.1:- management plan.

\begin{tabular}{|l|l|l|l|}
\hline Sr. No. & Treatment & Dose & Duration \\
\hline 1 & Cap ayucal p & $250 \mathrm{mg}$ bd with milk after meals & 30 days \\
\hline 2 & Cap shallaki & $400 \mathrm{mg}$ bd after meals & 30 days \\
\hline 3 & Panchtikta ghrita guggul & $1 \mathrm{gm}$ thrice a day after meals & 30 days \\
\hline 4 & Patrapinda swedan & & 15 days \\
\hline
\end{tabular}

Each capsule of ayucal p contains praval pishti $250 \mathrm{mg}$. Each capsule of shallaki contains extract of shallaki $400 \mathrm{mg}$. Panchtikta ghrita guggul was according the reference of bhaishajya ratnavali ${ }^{14}$.

Patra pinda swedan ${ }^{15}:-$

Pre-procedure:-

The fresh leaves of nirgundi (vitex negundo), 500gm in quantity were collected and chopped into small pieces. Required quantity of eranda oil was taken in pan and heated. Slices of 4 lemons were added into it. When the lemon slices became slightly fried the powder of shatahwa and methika $100 \mathrm{gm}$ was added. When the mixture turned brownish saindhav was added and stirred well. Then the leaves were added. When the leaves were fried the mixture was taken out. The sliced leaves and the other ingredients which were fried and processed in the herbal oils were tied in a clean cloth. The upper free ends of the clothes were tied with strong thick threads so as to form a bolus of leaves i.e. Patra pinda. Four boluses were prepared.

Procedure the bolus was dipped in oil which is kept on heating apparatus at a constant temperature in pan. The patra pinda were gently rubbed with mild pressure in the manner similar to the abhyanga. The treatment procedure was carried out for 30 minutes.

\section{Observation \& result:-}

Table no. 3 :- assessment on day $1,15 \& 30$.

\begin{tabular}{|c|c|c|c|c|}
\hline $\begin{array}{l}\text { Sr } \\
\text { no }\end{array}$ & Assessment parameter & Day 1 & Day 15 & Day 30 \\
\hline 1. & Haemoglobin & $10.2 \mathrm{gm} / \mathrm{dl}$ & $10.1 \mathrm{gm} / \mathrm{dl}$ & $10.3 \mathrm{gm} / \mathrm{dl}$ \\
\hline 2. & ESR (fall in $1^{\text {st }}$ hour) & $28 \mathrm{~mm}$ & 26 & 23 \\
\hline 3. & Vatapurnadritisparsa & Audible crepitus & Palpable crepitus & Palpable crepitus \\
\hline 4. & Shotha & Moderate & Mild & Absent \\
\hline 5. & Sandhi shoola & Severe & Mild & Mild \\
\hline 6. & Prasaranakkunchana pravriti savedana & $\begin{array}{l}\text { Prevent complete } \\
\text { flexion }\end{array}$ & $\begin{array}{c}\text { Pain with } \\
\text { winching of face }\end{array}$ & $\begin{array}{c}\text { Pain without } \\
\text { winching of face }\end{array}$ \\
\hline 7. & Walking distance & 50 meters & 100 meters & $2 \mathrm{~km}$ \\
\hline
\end{tabular}

After treatment with patra pinda swedan for 15 days and with medicines for 1 month, patient reported very good relief in all the symptoms. 


\section{Discussion:-}

Tab ayucal p contains praval pishti, which is a natural source of calcium. Calcium is the most obvious and persistent of the micronutrients, the fifth most abundant element in the body. Calcium is an important mineral component of our diet. Calcium supplementation can play a valuable role in bone health throughout the lifecycle. An adequate calcium intake through proper selection of calcium salt is therefore only one of many measures to ensure a healthy skeleton $^{16}$.

Shallaki possesses tikta (bitter), madhura (sweet) and kashaya (astringent) rasa (taste); guna (quality) of shallaki is ruksha (dry), laghu (light) and tikshna; vipaka (post-digestive effect) is katu (pungent); whereas virya (strength or effect) is ushna. The doshakarma is kapha-pitta shamaka. According to classics, shallaki has potent vata-kaphahara properties $^{17,18}$. The key constituents of shallaki are volatile oil (4-8\%), acid resin (56-65\%) and gum (20-36\%). The triterpenoids are the active constituents and are collectively called boswellic acids. The gum resin of b. Serrata usually contains $43 \%$ boswellic acids, which contain a combination of six major constituents, mainly 3 acetyl, 11 keto, boswellic acids (akba), which help to preserve the structural integrity of joint cartilage and maintain a healthy immune mediator cascade at a cellular level ${ }^{19}$, which is active against pain and inflammation by inhibiting leukotriene synthesis. Specifically, it inhibits the activity of the enzyme 5 lipoxygenase through a non-redox reaction in $\mathrm{OA}^{20}$.

Panchtikta ghrita guggul is a complex compound containing many herbs and guggul. Classical references and clinical suggest it is highly beneficial in the management of sandhivata ${ }^{21}$.

Patra pinda swedan is therapeutic technique where snehan and swedan are applied using herbs and oils. Leaves of medicinal plants having analgesic and anti-inflammatory properties are the important ingredient of the procedure. Patra pinda sweda relieves pain, stiffness and swelling associated with arthritis and other painful conditions, pacifies the morbidity of vata, pitta and kapha in the affected joints, muscles and soft tissues, causes sweating and brings about lightness and a feeling of health in the affected joints, muscles and soft tissues. Patra pinda sweda is highly effective in the management of pain. In pain related arthropathies, before shodhana like virechana, patra pinda sweda is effective. It is indicated in intervertebral disc protrusion or prolapsed (ivdp), sciatica (gridhrasi), osteoarthritis, chronic stages of RA (jeerna or pravruddha amavata), cervical spondylosis, ankylosing spondylitis, frozen shoulder, pakshavadha (hemiplegia) etc ${ }^{15}$.

\section{Conclusion:-}

Osteoarthritis is a very common condition. People who suffer from this disease are usually sufferers for their life. Management is usually difficult at later stages of the disease. Patient treated and presented as this case study got remarkable relief. Therefore it can be concluded that use of classical ayurvedic treatment in the background of accurate diagnosis can be helpful for the patients suffering from osteoarthritis. To avoid painful intervals, advancement of the disease and repeated use NSAIDS, ayurvedic management is the only option. Use of external therapies like patra pinda swedan offers additional advantage of reducing exposure to oral medications. This study will be helpful for further collaborative research with modern medicine in the cases of end stage osteoarthritis.

\section{Referances:-}

1. Bhavaprakasha of bhavamishra, english translated by prof. K.r. srikanta murthy vol. 2, part ii page no - 348 .

2. Sharma p v. (2005) caraka samhita of agnivesha. Edn \&th. Vol-ii. Chaukhamba orientalia, varanasi.; 462.

3. Babu m s r. Yoga ratnakara, edn $2^{\text {nd }}$. Vol-i. Chaukamba sanskrit series, varanasi. 2011; 602.

4. Shastri k. (2009) charak samhita of agnivesha. Reprint edition. Chaukhamba sanskrit sansthan varanasi. 697.

5. Anthony s. Fauci, eugene braunwald, editors. (2008) harrisons principles of internal medicine, $17^{\text {th }}$ edn, mc graw hill medical; 2158.

6. Walker b r, colledge $\mathrm{n} \mathrm{r}$, ralston s h, penmon i. (2014) davidson's principles and practice of medicine. Edn $22^{\text {nd }}$. 1081.

7. Ringdahl e, pandit s. (2011) treatment of knee osteoarthritis. Am fam physician. 83: 1287- 92.

8. Murray cjl, vos t, lozano $r$ et al. (2010). Disability-adjusted life years (dalys) for 291 diseases and injuries in 21 regions, 1990-2010: a systematic analysis for the global burden of disease study. The lancet.; 380: $2197-2223$.

9. Vos t, flaxman ad, naghavi $\mathrm{m}$ et al. (2010) years lived with disability (ylds) for 1160 sequelae of 289 diseases and injuries 1990-2010: a systematic analysis for the global burden of disease study. The lancet. 380: 21632196. 
10. Cross m, smith e, hoy d, nolte s, ackerman i, fransen m, et al. (2014)the global burden of hip and knee osteoarthritis: estimates from the global burden of disease 2010 study. Annals of the rheumatic diseases; 73(7): 1323-1330.

11. Acharya jt. (2011)charaka samhita of agnivesha. Edn $1^{\text {st }}$. Chaukhamba sanskrit sansthan. Varanasi; 618.

12. Acharya y t. (2011) agniveshakrita charaka samhita, chakrapani commentary chaukhambha surbharti prakashan. Varanasi. 624.

13. Acharya y t. (2010) agniveshakrita charaka samhita,chakrapani commentary, chaukhambha surbharti prakashan. Varanasi: 620.

14. Mishra s n. (2005) bhaishajya ratnavali of kaviraj govind das sen. Part i. Chaukhambha surbharti prakashan, varanasi; 882.

15. Nirmal bhusal et al. (2017)review on patra pinda sweda: a peculiar ayurveda bolus fomentation. International. Ayurvedic medical journal. 1760-1764.

16. Trailokya a, srivastava a, bhole $\mathrm{m}$, zalte $\mathrm{n}$. (2017) calcium and calcium salts. Journal of the association of physicians of india. Vol. 65: 100-103.

17. Pande g s, chunekar k c. (2006) bhava prakasha of bhavmishra. Chaukhamba bharti academy, varanasi: 212.

18. Pande g s, chunekar k c. (2006) bhava prakasha of bhavmishra. Chaukhamba bharti academy, varanasi: 521.

19. Kimmatkar n, thawani v, hingorani 1, khiyani r. (2003) efficacy and tolerability of boswellia serrata extract in the treatment of osteoarthritis of knee: a randomized double blind placebo controlled trial phytomedicine. 37.

20. Dev sa, (2006) selection of prime ayurvedic plant drugs: ancient-modern concordance. New delhi: anamaya publishers; 113-117.

21. Akhtar b, mahto r r, dave a r, shukla v d. (2010) clinical study on sandhigata vata w.s.r. To osteoarthritis and its management by panchtikta ghrita guggulu. Ayu; 31/1: 53-57. 